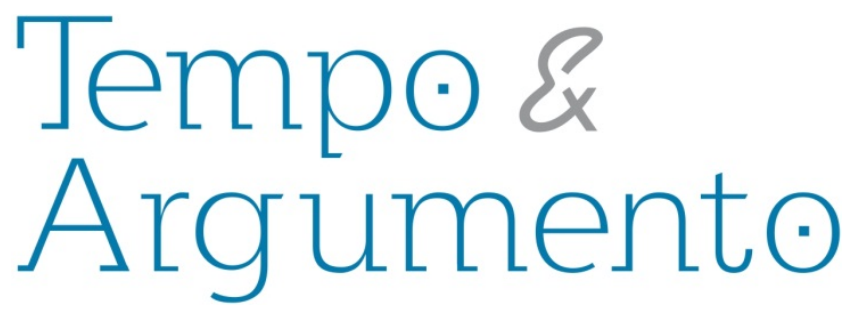

\title{
Constelaciones de la memoria: sobre Nostalgia de la Luz [2010] y El Botón de Nácar [2015] de Patricio Guzmán
}

\begin{abstract}
Resumen
Nostalgia de la Luz [2010] y El Botón de Nácar [2015] son parte de una trilogía a cargo del documentalista chileno Patricio Guzmán. En estas dos películas el autor se propone una reflexión sobre la memoria histórica y política de Chile. Lo singular de su propuesta son los elementos aparentemente disímiles que participan del diálogo. Es así como los pueblos originarios del sur de Chile y los desaparecidos de la dictadura de Pinochet se urden en un entramado con el desierto de Atacama, la astronomía, las mujeres buscadoras de Calama, el agua y los botones de nácar, entre otros hilos de la historia. El resultado es un tejido del tiempo, una posible relación con este, con todo aquello que implica pensarlo -historia, ciencia, ética, territorios, relaciones- o como pensamiento de lo impensable. ¿Qué elementos traman las imágenes de lo real que Guzmán propone? ¿Cuál es la potencia de estas imágenes? Si pensamos en ellas cual vórtice que interrumpe el flujo de la corriente de las imágenes-movimiento, ¿hacia dónde rota nuestro lazo con el mundo?, ¿qué nos depara creer con lo impensable?, ¿qué implica imaginar el caos? Para ensayar algunas respuestas posibles y de este modo dar cuenta de ciertos aspectos del problema de lo real en el documental contemporáneo, me propongo el análisis de estos dos films en función de tres vértices: 1) la creencia, 2) la imaginación y 3) el tiempo, considerando que estos trazan una cartografía de la memoria que los dos films de Guzmán visibilizan.
\end{abstract}

Palabras clave: Documental. Memoria. Imaginación.

Creencia. Tiempo

\section{Para citar este artículo:}

ZARINI, María Emilia. Constelaciones de la memoria: sobre Nostalgia de la Luz [2010] y El Botón de Nácar [2015] de Patricio Guzmán. Tempo e Argumento, Florianópolis, v. 9, n. 21, p. 74 - 93 , maio/ago. 2017.

DOI: $10.5965 / 2175180309212017074$

http://dx.doi.org/10.5965/2175180309212017074 


\section{Constellation of memory: about Nostalgia de la Luz [2010] and El Botón de Nácar [2015] by Patricio Guzmán}

\begin{abstract}
Nostalgia de la Luz [2010] and El Botón de nácar [2015] are part of a trilogy made by the documentalist Patricio Guzmán. In these two films the author proposes a reflection on Chile's historical and political memory. The singular of his proposal are the apparently dissimilar elements that participate in the dialogue. This is how the indigenous peoples of southern Chile and the disappeared of the Pinochet dictatorship get involved in the same plot with the Atacama Desert, astronomy, women seeking Calama, water and mother-of-pearl buttons, among other projections of the history. The result: a time's tissue, a possible relationship with it, with everything that implies thinking -history, science, ethics, territories, relationships- or as a thought of the unthinkable. What elements paint the images of the real that Guzman proposes? What is the power of these images? If we think of them as a vortex that interrupts the flow of the torrent of images-movement, where it rotate our relationship with the world? What does it imply to believe in the unthinkable? What does it mean to imagine chaos? In order to test some possible answers and thus to give an account of certain aspects of the real problem in the contemporary documentary, I propose the analysis of these two films in three vertices: 1) belief, 2) imagination and 3) the time, considering that these trace a cartography of the memory that the two films of Guzman visualize.
\end{abstract}

Keywords: Documentary. Memory. Imagination. Belief. Time.

\section{Constelações da memoria: sobre Nostalgia de la Luz [2010] e El Botón de Nácar [2015] de Patricio Guzmán}

\section{Resumo}

Nostalgia de la Luz [2010] e El Botón de nácar [2015] são parte de uma trilogia do chileno documentarista Patrício Guzmán. Nestes dois filmes o autor propõe uma reflexão sobre a memória histórica e política do Chile. A singularidade da proposta são os elementos, aparentemente diferentes, envolvidos no diálogo. Assim, os povos indígenas do sul do Chile e os desaparecidos da ditadura de Pinochet participam do mesmo argumento com o Deserto de Atacama, a astronomia, as mulheres de Calama, a água e os botões de nácar ou madrepérola, entre outros tópicos da história. O resultado é um tecido do tempo, uma possível relação com ele, com tudo aquilo que implica pensá-lo -história, ciência, ética, territórios, relações- ou como o pensamento do impensável. Quais são os elementos que compõem a trama das imagens do real que Guzmán propõe? Qual é o poder dessas imagens? Se pensamos nelas como um vórtice que interrompe o fluxo de imagensmovimento, para onde gira nossa relação com o mundo? Com o quê nos deparamos ao acreditar com o impensável? O que implica imaginar o caos? Para testar algumas respostas possíveis e, portanto, pensar determinados aspectos do problema da realidade no documental contemporâneo, proponho analisar estes dois filmes baseado em três pontos: 1) crença, 2) imaginação e 3) tempo, considerando que estes traçam uma cartografia da memória que ambos filmes de Guzmán evidenciam.

Palavras-chave: Documentário. Memória. Imaginação. Crença. Tempo. 


\section{"El cine se declara culpable" ": INTRODUCCIÓN}

La memoria “obstinada”, la "obstinación" con la memoria, la "obstinación” por la memoria. Patricio Guzmán y su cine caben en este juego de palabras desde hace tiempo. ¿Por qué dirige su mirada al pasado? ¿A dónde quiere llegar? Para dar con algunas respuestas posibles sería oportuno, tal como afirma Epstein (2014, p.66) "rendirse ante esta chocante constatación: de una parte, la precisión y la inmutabilidad, de otra parte la fidelidad a lo real, forman cualidades contradictorias en perpetuo balance de compensación en un equilibrio siempre por recobrar" . En este sentido y renunciando a pretensiones categóricas, observo en ciertas situaciones dialógicas de Nostalgia de la luz y de El botón de nácar la posibilidad de re-conocer el valor puramente problemático que anida en dichas imágenes en tanto imágenes de lo real. En esta ocasión me permito abordar tal valor considerando que en las imágenes de ambos documentales prima la síntesis -y no el análisis- como procedimiento de creación y de modificación de las nociones de forma, movimiento, espacio y tiempo. Pero, ¿hacia dónde nos conduce esto? Una posibilidad es ver en estos dos films un ejercicio de la memoria que apuntala -con la imaginación como su principal recurso- un intento por creer con lo impensable, por (re)fundar nuestro vínculo con el mundo, a la vez que refuerza un tiempo propio, de tiempos flotantes (Epstein) que posibilitan la memoria en otras de sus variantes y en pos de hacer frente a la máquina de desimaginación (Didi-Huberman) que impone el olvido de las historias de Chile. Por tanto, luego de una breve introducción a los films, ahondaré en las nociones de creencia, imaginación y tiempo (puntos nodales del valor problemático). Las conclusiones darán cuenta que si de algo son "culpables" los documentales de Guzmán es de "una nueva concepción del universo y [de] nuevos misterios en el alma" (EPSTEIN, 2014, p.2) que nos alejan del olvido y nos acercan al conocimiento.

\footnotetext{
${ }^{1}$ Epstein, Jean (2014) El cine del diablo. Buenos Aires, Cactus, p.2
} 
Figura 1: Mujer de Calama

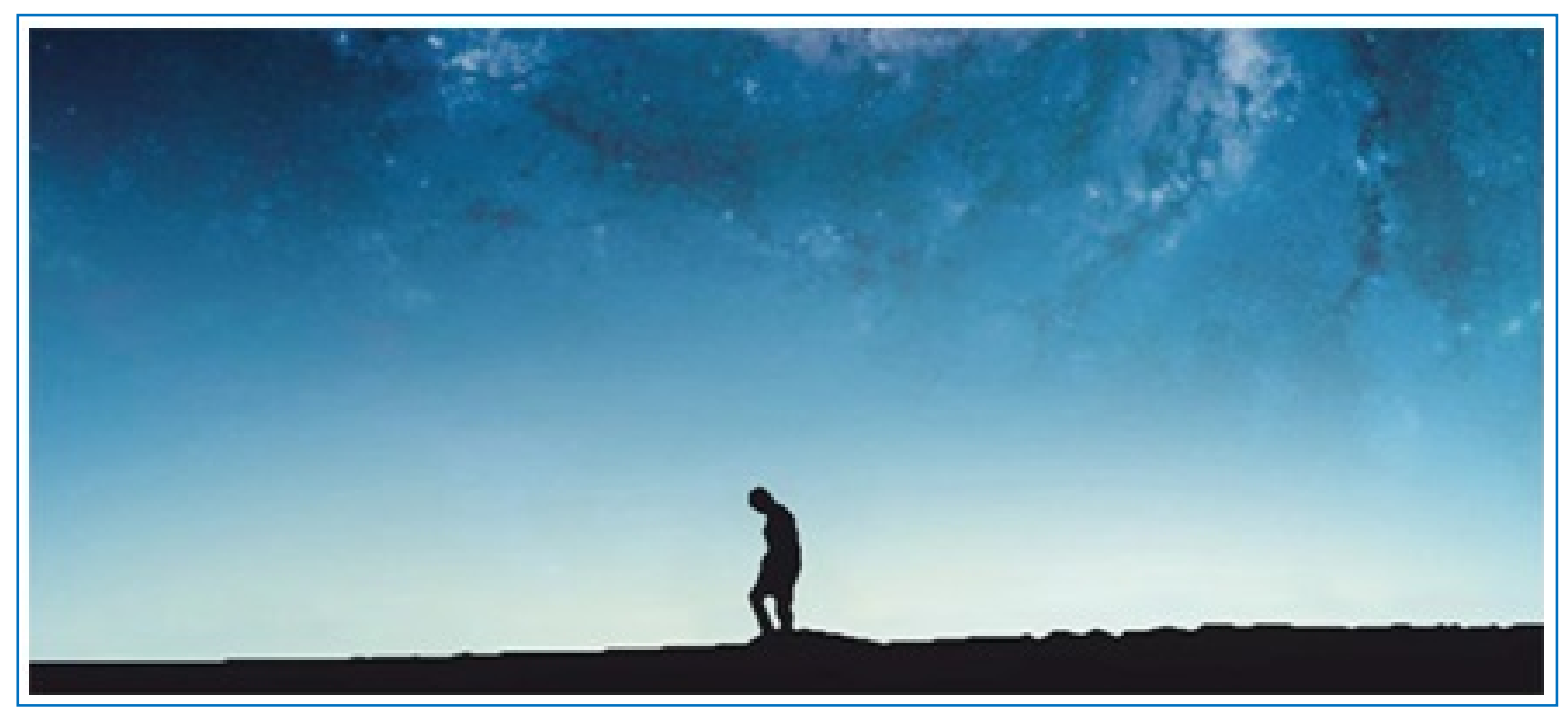

Fuente: Nostalgia de la luz [Patricio Guzmán, 2010]

\section{Luz de nácar: LOS FILMS}

"Nostalgia de la Luz es un film sobre la distancia entre el cielo y la tierra, entre la luz del cosmos y los seres humanos y las misteriosas idas y vueltas que se crean entre ellos. En Chile, a tres mil metros de altura, los astrónomos venidos de todo el mundo se reúnen en el desierto de Atacama para observar las estrellas. Aquí, la transparencia del cielo permite ver hasta los confines del universo. Abajo, la sequedad del suelo preserva los restos humanos intactos para siempre: momias, exploradores, aventureros, indígenas, mineros y osamentas de los prisioneros políticos de la dictadura. Mientras los astrónomos buscan la vida extra terrestre, un grupo de mujeres remueve las piedras: busca a sus familiares"

El botón de nácar: "el océano contiene la historia de la humanidad. El mar guarda todas las voces de la tierra y las que vienen desde el espacio. El agua recibe el impulso de las estrellas y las transmite a las criaturas vivientes. El agua, el límite más largo de Chile, también guarda el secreto de dos misteriosos botones que se encuentran en el fondo del océano. Chile, con sus 2670 millas de costa y el archipiélago más largo del mundo, presenta un paisaje sobrenatural. En ella están los volcanes, montañas y glaciares. En ella

\footnotetext{
${ }^{2}$ Nostalgia de la luz. La película. Disponible en: http://nostalgiadelaluz.com/la-pelicula/ Acceso: 10 de abril de
} 2017. 
están las voces de los indígenas patagones, los primeros marineros ingleses y también los prisioneros políticos. Se dice que el agua tiene memoria. Este film muestra que también tiene una voz"3.

\section{"posible, o me ahogo"4: CREENCIA}

Quizá aquello que nos impresiona, aquello que nos con-mueve es ver estos dos films de igual modo en que se experimenta el ejercicio mismo de la memoria. No se trata simplemente de la tracción de recuerdos aislados. La memoria es una fuerza de gravedad, afirma Guzmán. Te atrae hacia sí, desde el acontecimiento más lejano hasta el corazón del tema. Pero al mismo tiempo es el efecto de deformación que la evocación produce sobre el espacio-tiempo que habitamos hoy. De forma análoga, los hechos de cada película imantan nuestro presente y van produciendo pequeñas dislocaciones que nos ponen a gravitar, finalmente, en torno a la memoria, esa fuerza misteriosa que fisura nuestro tiempo.

En este sentido, podríamos afirmar que Guzmán hace el intento de unir el cine con la realidad más íntima de nuestro cerebro. Si lleva a cabo esta tentativa es porque cree en el cine y al hacerlo “(... ) le acredita no el poder de hacer pensar el todo sino, por el contrario, una «fuerza disociadora» que introduciría una «figura de nada», un «agujero en las apariencias»" (DELEUZE, 1987, p.224). Nuestra realidad más íntima, lejos de ser un Todo, es una hendidura por la que las imágenes de Guzmán ingresan y fuerzan al pensamiento hacia ese Todo que no puede pensarse, hacia lo inevocable, hacia lo inefable, hacia lo infinito.

¿Cómo no ahogarnos en lo impensado? ¿Cómo no sucumbir ante lo inabarcable? Precisamente fundando una creencia a partir de ello, o mejor dicho con ello: que la creencia sea el pensamiento de lo impensable. Pero, ¿por qué fundar una nueva creencia?, ¿a qué hacemos referencia cuando proferimos creer con lo impensable? $Y$ finalmente, creer ¿para qué?

3 El botón de nácar. Disponible en: http://www.imdb.com/title/tt4377864/plotsummary?ref_=tt_ov_pl. Acceso:10 de abril de 2017

${ }^{4}$ DELUEZE, Gilles (1987) La imagen tiempo. Estudios sobre cine 2. Paidós. Buenos Aires, p.227 
Hemos dejado de creer en el mundo. Quizá, la crueldad despiadada de nuestra barbarie civilizada tenga mucho que ver en ello. Acaso, haber asfixiado intentos por un mundo mejor tenga que ver otro tanto. Ya no tenemos fe en los encadenamientos de la costumbre o de la tradición, aquellos que nos permiten reconocer el dato y su prolongación en acción. $Y$ por eso no reaccionamos. De algún modo -obtuso y unívocomantenemos esta conexión sensorio-motriz con el mundo que se vuelve intolerable, y nosotros no somos algo distinto de él. Pasamos a habitar el caos, aunque por tradición nos repugne, pero presentimos que algo hay que extraer de allí, que alguna salida tiene que haber (ZOURABICHVILI, 2007). Entonces, la creencia surge como alternativa a la identificación por esquemas estereotipados; brota para restablecer aquel vínculo que entre las personas y el mundo se ha perdido. Creer en el mundo es la premisa. No creernos otro mundo, sino parte de éste. Tampoco depositar la fe en un mundo distinto o transformado. Sino "Creer en este mundo como lo imposible, vale decir, en sus potencialidades creadoras o en la creación de posibles" (DELEUZE, 1997, p.72).

Ahora bien, ¿cuál es la función del cine en el régimen de la creencia? El cine debe filmar esta creencia, debe producirse con la creencia en el mundo, y es de ella y no del mundo en sí por quien debe preocuparse. El cine, entonces, tiende un puente a las personas con su mundo. Le permite enlazarse con la situación óptica y sonora que lo rodea. Cada experiencia cinematográfica -tal como lo son los dos films de Guzmán en cuestión- lo hacen de una manera posible entre otras múltiples formas de hacerlo. De este modo es que el cine adopta una posición de creencia que permite el conocimiento del mundo y aleja a las personas de una actitud solipsista. En este sentido es que el cine encarna la potencialidad creadora que el mundo emana. "Pues de lo que se trata es de reencontrar; de volver a dar creencia en el mundo, más acá o más allá de las palabras" (DELEUZE, 1987, p.230).

Hay un evidente reemplazo del saber por la creencia como modo de conocer el mundo. Es preciso aclarar que no se trataría de una nueva creencia sino de una creencia otra, distinción que responde a lo que el semiólogo Walter Mignolo (2013) postula en relación a "lo nuevo y lo otro" a saber: hablar de una nueva creencia significaría referirse a una nueva relación con el mundo que se autopresenta como una nueva verdad que 
continúa la univocidad que la precedió. Mientras que postular una creencia otra implicaría considerar otras relaciones posibles además de esa, es decir, contemplar la diversidad de la creencia apelando al sentido más comunitario de la misma.

\section{"qué tristeza tendrá el cielo al fin cuando se sepa inventado"5: IMAGINACIÓN}

La creencia, entonces, me impulsa a utilizar mi imaginación para crear mi relación con el mundo. Las películas de Guzmán se hacen eco de este recurso que no se reduce a ser una técnica. La imaginación es potencia, es posibilidad, es pensamiento de lo impensable. "Un planeta descubierto desde Chile tiene un océano de gran tamaño, ¿tendrá este vida, tendrá árboles para hacer canoas, hubiera sido un planeta de asilo? Pensar esto es irreal pero me atrevo a hacerlo porque me gustaría que estos pueblos del agua no hubieran desaparecido." Guzmán se aventura a imaginar para creer.

¿Es, por tanto, uno de los niveles posibles de la creencia? Es, sí, parte de aquello que enlaza los datos que ambos documentales (re)presentan. Es uno de los hilos que cose las narraciones en cuestión. Dichos lazos operan entre los datos de cada pieza, en la totalidad que cada obra representa por separado, y también entre ambas obras. Guzmán (2012) declara ser consciente que la cartografía de la memoria se construye de este modo: con y desde la imaginación que surge del seno mismo del régimen de creencia de los sujetos filmados y de las experiencias que estos transitan.

En el caso de la astronomía hay claros ejemplos:

En la investigación científica además de la plataforma matemática, también hay intuición e inspiración. Hubo una de las investigadoras que entrevisté, se llama María Teresa, que dice que hay un talento artísticocreativo para hacer descubrimientos en la astronomía. Cada uno tiene un talento de búsqueda. Ella, por ejemplo, es coleccionista de ágatas, unas piedras que el mar pule durante miles de años y arroja a la costa. En un momento del documental muestro unas de su colección, parecen asteroides que atrapan la luz. Uno está en la playa y ve una cosita pequeña que brilla. Es un ágata. Ella dice que con la astronomía es igual, hay que mirar las estrellas y de entre los miles de millones detectar una que tiene algo distinto. (GUZMÁN, 2012).

\footnotetext{
${ }^{5}$ Coplas de Tata Dios, Gustavo ‘Cuchi’ Leguizamón.
} 


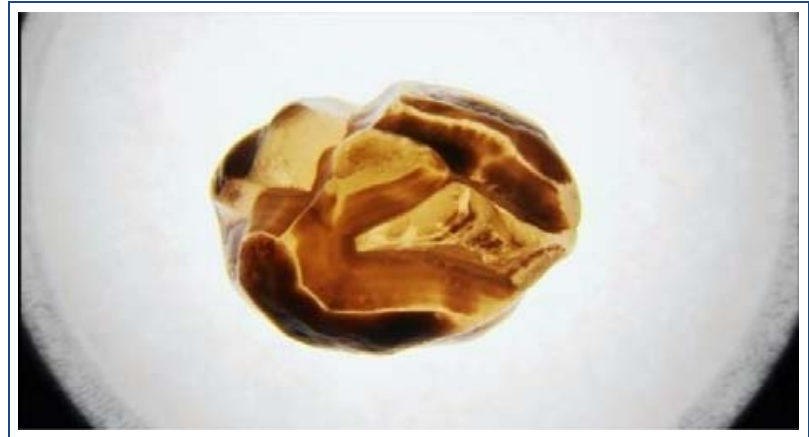

Fuente: Nostalgia de la luz [Patricio Guzmán, 2010]

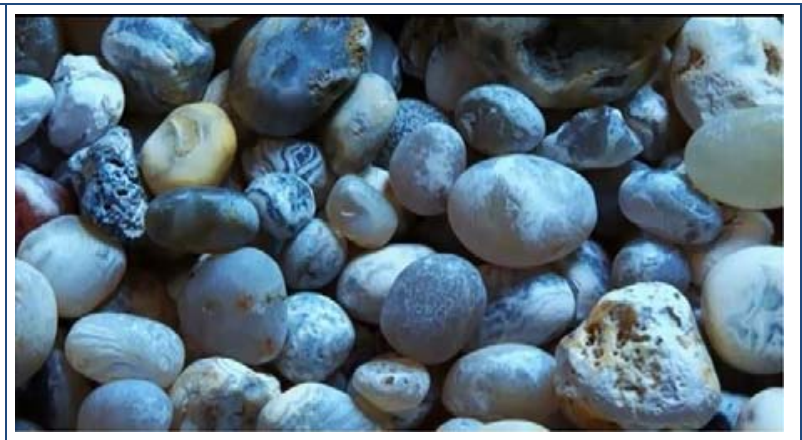

Fuente: Nostalgia de la luz [Patricio Guzmán, 2010]

Quizá esta anécdota logre dar cuenta de las dos acepciones que conviven en el régimen de fe que el documentalista busca y recibe erguido desde un punto de encuentro que se ubica en el "centro" de las ficciones que los alberga a todos. El estudio de los cuerpos celestes, por ejemplo, pertenece (a priori) al dominio de la ciencia. Por tanto, formaría parte de un conocimiento inteligible al que le correspondería una realidad homónima. Sin embargo, Guzmán explora y despliega un conocimiento sensible en relación a este punto de partida. “Ahora creo que las raíces pueden estar arriba, más allá de la luz", afirma el director luego de recorrer el desierto de Atacama, aquel donde pudo encontrarse tanto con restos fósiles de un prehistórico mar, como con telescopios con la más avanzada de las tecnologías, como con las mujeres que buscan los restos de sus familiares desaparecidos por la dictadura pinochetista.

En consonancia, el astrónomo que Guzmán entrevista afirma:

Yo creo que los dos trabajamos con información del pasado para aprender lecciones del pasado (...) Lo que hacen estas mujeres es parecido a lo que hacen los astrónomos con la diferencia sustancial de que pueden trabajar con el pasado de manera pacífica, mientras que ellas no pueden dormir tranquilas aún buscando en el pasado (GUZMÁN, 2015).

Su creencia y su imaginación le permiten una interpretación comunitaria de la hipótesis del documental (aunque lo haga de forma involuntaria). Su intuición es el gesto 
Así es que la creencia oscila de modo inevitable entre lo sensible y lo inteligible. $\mathrm{Ni}$ el mundo de la opinión ni el mundo de la fe permanecen en perfecta cuarentena. Por algún intersticio se produce el contagio y de este modo:

(... ) el pensador sólo conjura ese retorno de la trascendencia y la opinión si traza su plano de manera de envolver tanto como pueda (...) lo impensable que volvería a conducir al caos al pensamiento que se identificaría con él pero cuya afirmación no es menos necesaria para evitar la otra identificación, la de lo creado y lo originario." (ZOURABICHVILI, 2007, p.77)

Desde esta posición, Guzmán (2010) funda la hipótesis que contiene a ambos documentales:

La pregunta es ¿por qué hay territorios que se prestan para esto? (...) ¿Por qué hay astrónomos y arqueólogos viviendo en un mismo territorio? La respuesta es muy simple: porque en ese territorio la posibilidad de introducirse en el pasado es mayor que en otros.

Estamos en una puerta hacia el pasado.

Yo diría que sí, que es una puerta que sabemos cómo entrar, pero cómo vamos a salir de esto, es decir, con cuántos conocimientos que van a transformar la vida... esto para mí sigue siendo un misterio.

Y sin embargo, es un país que no trabaja su pasado. Está entrampado en un golpe de estado que lo tiene todavía inmovilizado.

Yo creo que esa es la paradoja que más te preocupa. Yo creo que ese es el meollo del punto. Yo creo que eso es lo que amerita tu preocupación y tus ansias y la comparto absolutamente.

Es una paradoja: el pasado más cercano a nosotros lo tenemos encapsulado (...) Qué poco sabemos del siglo 19, cuántos secretos guardamos del siglo 19. Nunca hemos dicho, en realidad, por qué arrinconamos a nuestros indígenas. Ese es casi un secreto de Estado. No hemos hecho absolutamente nada por entender porqué en el siglo 19 se generaron estos modelos económicos, vertiginosos como el salitre y que después no quedo nada. Nuestras historias más cercanas las hemos mantenido a un nivel de ocultamiento, de encubrimiento... Hay como un contrasentido, como que no queremos acercarnos a esa prehistoria cercana, como que sería casi una prehistoria acusatoria y eso, estimado amigo, no le sirve a nadie (NOSTALGIA DE LA LUZ, 2010:24'-27'). 
Si el director se privara de alguna de las entidades constitutivas que organizan el pasado chileno, si priorizase lo inteligible por sobre lo sensible, si dirimiese la realidad en verdadera o falsa, se perdería de muchas de las relaciones posibles entre las personas y el mundo, entre el pueblo chileno y su mundo. No lo hace y por eso hace jugar sus documentales en el tiempo interno de estas ficciones y no en su supuesta adecuación o desacople con una realidad verdadera. Ficciones que, además, pasan a través de la visión de mundo de Guzmán, a través de su filtro ideológico, de sus intereses, lo que no da, por tanto, una percepción entera de la cosa. Su imagen no es una imagen entera. Es un corte, un tamiz del caos que hace el intento por devolver las personas -y con ellas el mundo-a un país que ha sido apresado por un pasado ignoto, impensable.

Esta creencia es, posiblemente, el elemento fundamental del cine de Guzmán. Si hablamos de creencia es porque concebimos la imagen como una operación constructiva, es decir, como manipulación que equivale a múltiples maneras de concebir distintas relaciones entre el mundo y 'yo': yo-realizador, yo-espectador, yo-personaje del film. Sobre cada uno de estos niveles de relación se cimienta la fe. A partir de cada una de estas relaciones se recupera el mundo, los cuerpos y las voces, desde lo que significa su ausencia. Porque de esto se tratan Nostalgia de Luz y El botón de nácar: de recuperar el pasado pero no para una construcción simplemente revisionista que satisfaga la actualización de los datos, sino porque hay cuerpos y hay voces que son "el pasado de lo que hoy somos" (GUZMÁN, 2010) y que se vuelve imperioso darles encuentro con el presente, aunque este sea una "línea muy delgada. [Que si] Uno sopla un poquito (...) se destruye" (GUZMÁN,2010).

Ocurre que la memoria es una de nuestras maneras posibles de habitar este mundo, de volver a encontrarnos con él, de volver a trazar vínculos, porque "Los que tienen memoria son capaces de vivir en el frágil tiempo presente. Los que no la tienen, no viven en ninguna parte" (GUZMÁN, 2010).

Guzmán toca los cuerpos y oye las voces de los telescopios y de los cuerpos celestes que estos acercan; del desierto de Atacama, de las pinturas rupestres y de los huesos de los trabajadores mineros; de las ruinas de Chacabuco, de las mujeres de Calama, y de los recuerdos de su infancia; de los cuerpos y voces del agua, del mar, de las 
pinturas cósmicas selk’nam, de los botones de nácar, de las palabras en kawésqar, del calcio en nuestros huesos, de los rieles en el lecho marino y de los cuásares... porque en él parece haber hecho mella lo que los pueblos del agua -selk'nam, kawésqar, aonikenk, haush, yámanas- creían del mundo: “Los pueblos americanos consideran que todo está vivo y tiene su espíritu. El agua es fuente de música. Todo lo que se mueve suena y tu universo se mueve, entonces suena" (GUZMÁN, 2015).

\section{“El tiempo intemporal”6: TIEMPO}

El revés de sus imágenes de lo real es una apuesta por una pregunta ética: ¿cuál es el sentido del pasado reciente y del pasado colonial en el presente y en el futuro del pueblo chileno? ¿Cuál es el sentido de traerlo al presente de sus narraciones? (aunque "todo ocurre en el pasado"). Una respuesta posible sería que propone un cine de constitución (DELEUZE, 1987), un cine que constituya cuerpos y con ellos una creencia en el mundo. (Re)encontrar los cuerpos de los primeros habitantes de la Patagonia occidental, "un lugar sin tiempo". (Re)encontrarlos con su agua, con su mar, con sus palabras (entre las que hay para nombrar a “foca, ballena, canoa, remo, papá, mamá, niño, Sol, Luna, estrella, playa, cholga, botón", pero no existe una para nombrar a dios ni tampoco una para policía), con su cielo de constelación de Orión y su Cruz del Sur, con las pinturas estelares de sus pieles. (Re)encontrar los cuerpos arrojados al mar o al desierto con las mujeres que los buscan incansablemente; con las estrellas que los reunían cuando presos observaban el transparente cielo; con el calcio cósmico que sus huesos compone; con los hijos, nietos y astrónomos que hoy son.

Entonces, Guzmán filma. Filma todo aquello que puede filmar. Insiste en buscar no lo que su cine pueda llegar a decir de las relaciones sociales de una época determinada, sino que avanza al preguntarse cómo colocarse en el interior de esas relaciones. Cómo posicionarse entre la astronomía y la búsqueda por el inmenso desierto que las mujeres de Calama hacen de los cuerpos ultrajados. Cómo posicionarse entre las ruinas de una mina devenidas ruinas del campo de concentración de Chacabuco y las estrellas que

\footnotetext{
${ }^{6}$ EPSTEIN, JEAN. (2015) La inteligencia de una máquina. Una filosofía del cine. Buenos Aires, Cactus, p.21
} 
desde allí observaban un grupo de detenidos; cómo hacerlo entre el espectro de una estrella y sus rastros de calcio, y el calcio que hay en nuestros huesos y en los de los arrojados y abandonados en el desierto; cómo colocarse entre su infancia y el universo. Cómo ubicarse entre la luz allendista y el eclipse pinochetista. Cómo hacerlo entre un bloque de cuarzo (hallado en el desierto, con 3000 años de antigüedad y con una gota de agua en su interior), el agua como la frontera más larga de Chile, los pueblos del agua (que viajaban, vivían y comían del agua) y el mar que recibió los cuerpos de detenidos desaparecidos arrojados desde un avión. Cómo colocarse entre las pinturas que los selk'nam se hacían a sí mismos, las constelaciones y la búsqueda de los antepasados; cómo situarse entre la historia de Jemmy Button, las palabras en kawésqar y los botones incrustados sobre los rieles atados a los cuerpos arrojados al mar; entre el cuásar y las almas errantes de los cuerpos que ya no están.

Cómo colocarse entre el pasado y el presente que no existe. Los testimonios que rescata son algunas de las respuestas: el astrónomo, el arqueólogo, las mujeres, el ex preso de Chacabuco que recorre las ruinas y completa los vestigios de nombres escritos en la pared; el "arquitecto de la memoria" y su mujer; Valentina (astrónoma e hija de desparecidos) y su pequeña bebé. El antropólogo que "aprendió el idioma del agua”, los últimos descendientes de los pueblos nativos de Chile, el poeta Raúl Zurita, los sobrevivientes del campo de concentración de Dawson, un participante de un vuelo de la muerte. También ensaya otras posiciones, otras imágenes de lo real, metafóricas, simbólicas: "Estos objetos que podrían haber sido los de mi casa"; las ágatas que asemejan el universo, o las bolitas que le recuerdan la inocencia de su infancia, "Cada uno podía tener el universo en su bolsillo." Los cráteres de la Luna, las piedras que tallaban los antiguos, las marcas sobre el suelo del desierto y las porosidades o depresiones de un cráneo humano, todo en fina sintonía. Los sonidos del agua, el canto del antropólogo, las palabras en kawésqar (botón se dice [ikenacar]). 


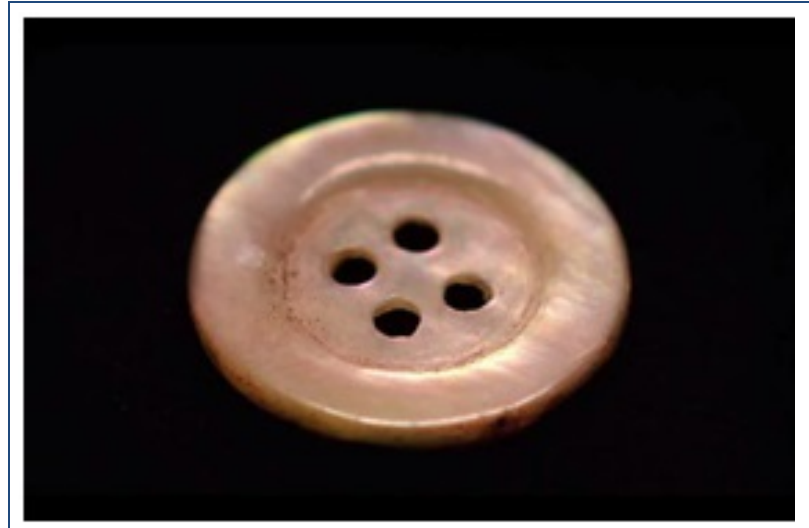

Fuente: El botón de nácar [Patricio Guzmán, 2012]

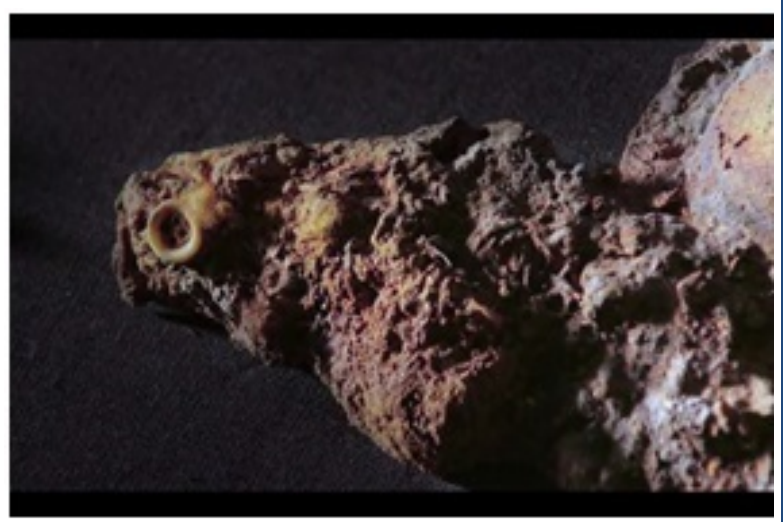

Fuente: El botón de nácar [Patricio Guzmán, 2012]
Figura 6: Escritos en el campo de concentración "Chacabuco"

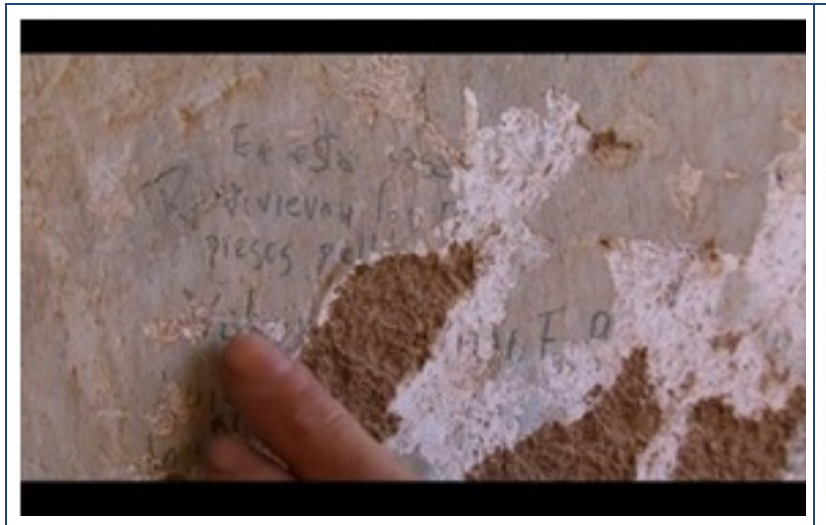

Fuente: Nostalgia de la luz [Patricio Guzmán, 2010]
Figura 7: Dibujos realizados por los pastores precolombinos en el desierto

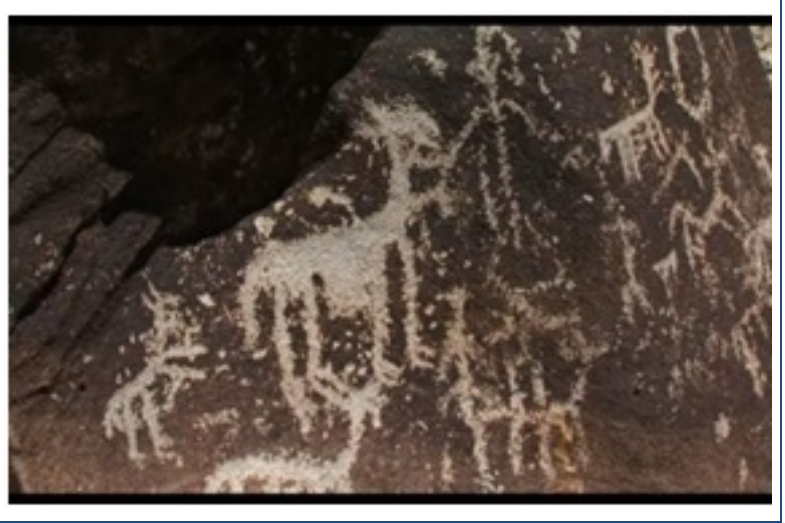

Fuente: Nostalgia de la luz [Patricio Guzmán, 2010]

Hay imágenes posibles; hay "imágenes pese a todo" (Didi-Huberman); pese a la distancia que“(...) también [es] tiempo en el pasado, aunque sea en millonésima de partes (...) Nada se ve forzosamente en el instante que se ve." Las imágenes nos provocan a construir lugares simbólicos y también reales que nos permitan fundar un vínculo comunitario, una interpretación colectiva de la creencia. Los dibujos del arquitecto, Miguel, las pinturas sobre los cuerpos selk'nam, el botón de nácar (de Jemmy Button o del riel) son algunos ejemplos de apuestas fuertes por parte de Guzmán. 
Intensos impulsos a relacionarnos con el mundo, a pensar lo impensado. Miguel, por ejemplo:

(...) un amante de las estrellas, paso por cinco lugares de detención donde contempló el cielo y utilizó su memoria para grabar cada cárcel en su mente. Cuando los militares vieron publicados los planos de los campos que ellos mismos habían desmantelado, quedaron estupefactos. (...) Uno, dos, dos y medio. Tres, cuatro, cinco, seis. Siete y medio.

Figura 8: Dibujos, realizados por Miguel, de los sitios de detención clandestinos,

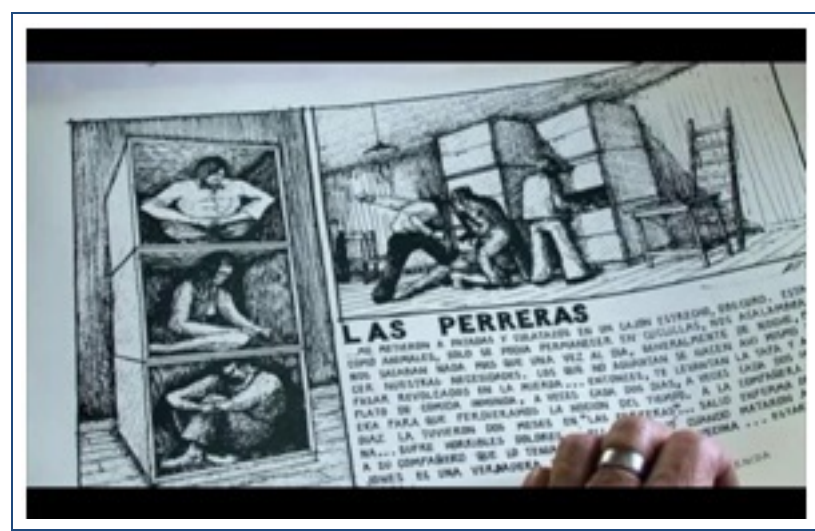

Fuente: El botón de nácar [Patricio Guzmán, 2012]
Figura 9: Dibujos, realizados por Miguel, de los sitios de detención clandestinos,

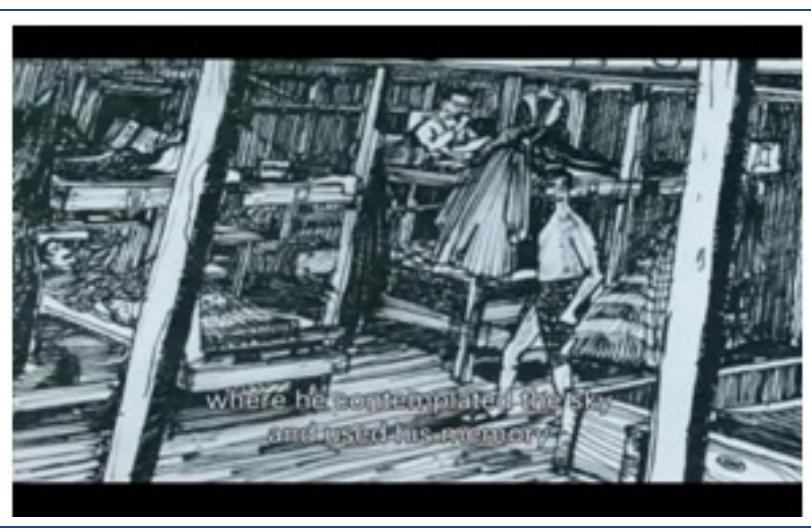

Fuente: El botón de nácar [Patricio Guzmán, 2012]

Miguel escenifica cómo medía los espacios para reconstruirlos en planos:

Cuando tomé la decisión de que había que dejar testimonio de lo que significaba un campo de concentración construido en Chile, inicie esta forma de medir exactamente todos los recintos, todos los espacios, con el objeto de ser capaz de dibujarlos algún día si es que salía en libertad.

Miguel representa el intento por plasmar lo inevocable, el horror de habitar un campo de concentración, y es eso lo que deja atónitos a los militares; los desconcierta su horror, la imagen de su horror, el hecho que tal imagen haya visto la luz. Es también lo que nos descoloca a nosotros, espectadores. Una imagen que nos devuelve una imagen del horror. Las imágenes de Miguel son una aproximación muy cercana a esta imagenlímite. La imagen de Guzmán (de las imágenes de Miguel) asume, como afirma Deleuze (1987) su aberración de movimiento [y por ende], opera una «suspensión de mundo», o 
afecta a lo visible con una «turbiedad» que, lejos de hacer visible el pensamiento (...) se dirigen, al contrario, a lo que no se deja pensar en el pensamiento y a lo que no se deja ver en la visión [225].

Eso que no se deja ver ni pensar es el horror, el dolor de los campos de concentración, del exilio, de la desaparición forzada de cuerpos arrojados al mar, tal como lo demuestra otro trabajo con la imaginación que Guzmán pergeña en El botón de nácar con el caso del cuerpo de Marta Ugarte, arrojado al mar y devuelto a la costa por la corriente de Humboldt. Guzmán dice elocuentemente: "He resuelto reconstruir los últimos momentos de una víctima para poder creérmelo." [60’] Procede, entonces, con la ayuda de un escritor y periodista, a la escenificación de lo que él imagina que han sido los últimos momentos de Marta Ugarte. Imagina cómo la empaquetaban, cómo le colocaban el riel, cómo fue muerta, cómo la arrojaron al mar, qué es lo que explica que su cuerpo haya Ilegado, luego, a la playa. Su imaginación busca la imagen-límite. Es una imagen incómoda que se construye desde la desconfianza. Es una imagen que fuerza a pensar (a sentir) un todo que no puede ser pensado. Hay algo que se nos escapa. Sentimos algo que no podemos aprehender en su totalidad. La imagen no atrapa todo; tampoco nada. Atrapa algo, lo retiene para que podamos activar una potencia, una posible relación con el mundo.

En la misma línea, es retórica aquella imagen que surge del gesto que Guzmán tiene al convocar a su amiga, la pintora Emma Malig. A través de ella, Guzmán (2015) se propone algo impensado: “Desde que era niño, jamás he podido ver una imagen entera de mi país (... Era necesario dividir Chile, en tres partes, el norte, el centro y el sur, como si fueran tres países" [23']. Tras esta cartografía, Guzmán construye mundo, (re)construye Chile, uno solo, y la imágenes que siguen a esta escena son honestas en relación a la propuesta de mundo que realiza allí, a la posición de creencia que encara desde aquí.

El ejercicio plástico que a través del mapa se realiza podríamos pensarlo como una cristalización de lo que pulsa a Guzmán a lo largo de sus dos films, que es el intento por disponer de 'todas' aquellas narraciones a partir de las cuales se constituyen los relatos sociales sobre la memoria política e histórica de Chile, de modo tal de hilar el entramado 
de relaciones que teja la creencia. La creencia que nos devolvería los cuerpos. Las relaciones que posibilitarían volver a creer en los cuerpos como gérmenes de vida.

Figura 10: Ejercicio plástico de Emma Malig

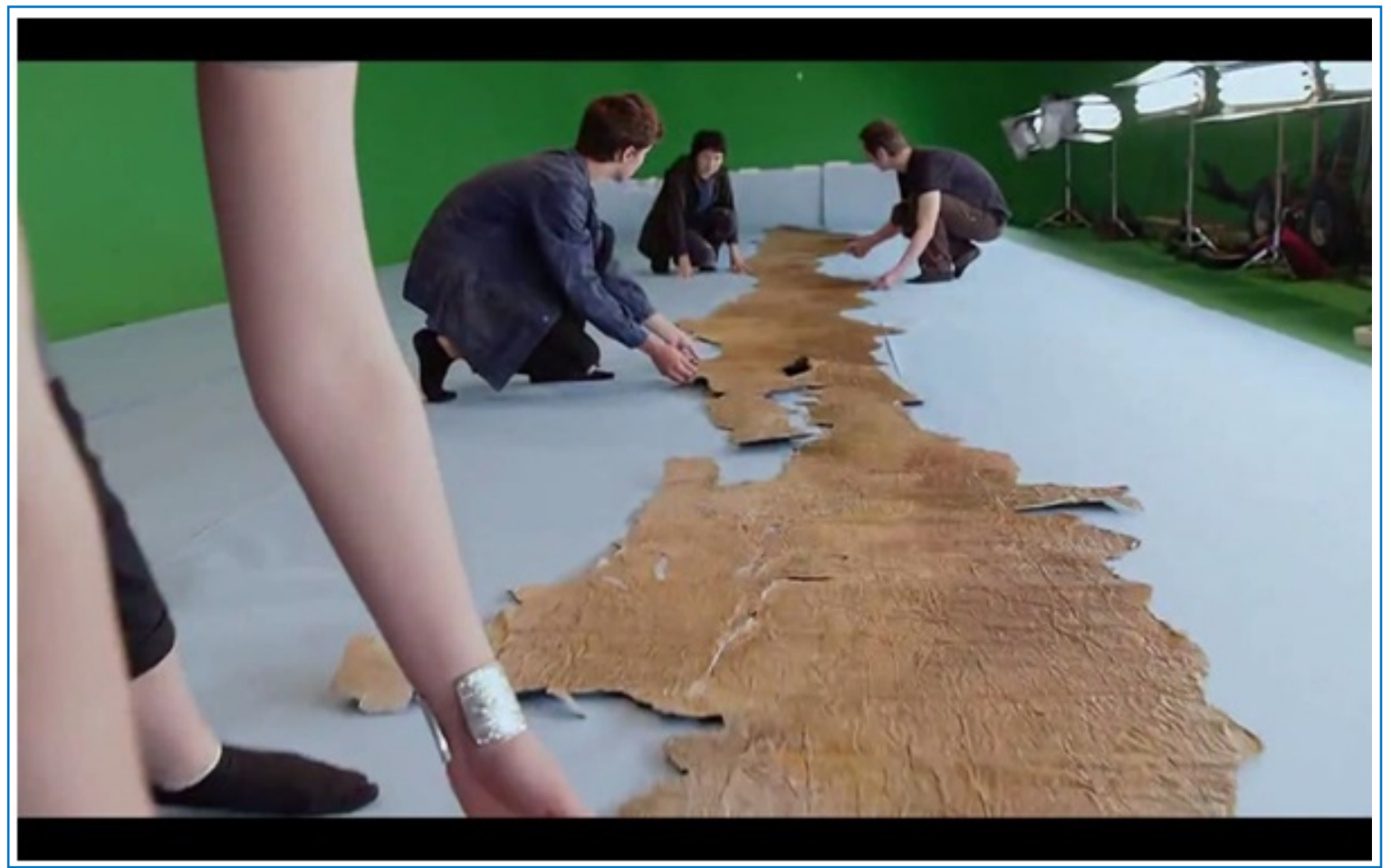

Fuente: El botón de nácar [Patricio Guzmán, 2012]

“(... ) como si el cielo hubiese sido la pared acribillada de un volcán en actividad que dejase entrever por sus orificios la incandescencia interna"7: CONCLUSIONES

Pulsar las cuerdas de los recuerdos. Acreditar que vibran. Que oscilan junto a otras memorias individuales. Que ondulan por una memoria colectiva en la que la creencia resulte pulsión de vida. El testimonio de Valentina, la astrónoma, condensa expresamente esta intención: “Como las estrellas que tienen que morir para que surja nueva vida. Y ese mismo camino recorre sus dolores que necesitan transformarse, seguir su ciclo para poder vivir. Crear otro espacio para poder ser feliz, para poder transitar con alegría”.

\footnotetext{
7 SAER, JUAN JOSÉ (2013) El entenado. Planeta, Buenos Aires, p.33
} 
Crear, por tanto, resulta imperioso. Construir otros espacios donde la experiencia sea posible; donde creer y conocer el mundo sea plausible; donde se batalle contra el olvido por sobreabundancia al que nuestras sociedades mediatizadas han dado tan cómodo lugar.

Lo que se abre paso, entonces, es la construcción de un espacio ficcional en el interior del cual la creencia es posible. Cada film aquí analizado funciona de este modo. Ambas películas abren espacios/tiempos en los que es posible creer: creer con las imágenes de Guzmán en el mundo y de este modo asistir -y a la vez asir- a una posible relación identificatoria e identitaria con el mundo. Imágenes constitutivas de una creencia, de cuerpos, de identidades. De memorias que ponen en tensión lo que queda del pasado en las vivencias de los grupos y de las individualidades que Guzmán dispone al diálogo.

Nostalgia de la luz y El botón de nácar, miradas diacrónicas sobre un pasado que se hace presente. Agentes de historias que disputan los sentidos de los acontecimientos que éstas evocan; que nutren los jirones de pasado que habitan en nosotros. Vectores de memoria que disponen de diversas fuentes, recursos y materiales para tejer tramas de una memoria social en la que se entrecrucen el "yo" y el "nosotros", el "nosotros" y el “ellos”, el “aquí” y el “allí”, el “presente” y el “pasado”, el “tiempo” y el “espacio”.

“Asomarse al mar [y también al cosmos] para asumirlo como un elemento de identidad." Creer en estos dos espacios como escenarios donde son factibles un sinnúmero de relaciones, de posibilidades que acrediten un vínculo entre las personas y su mundo. Podemos empezar a conocer el mundo si creemos que lo hay. Si no lo hacemos, si no creemos en el mundo, si no creemos en esos cuerpos desaparecidos, si no creemos en el agua y en los cuerpos celestes como fuentes de memoria, como gérmenes de vida, como voces que pueden ser oídas, nos sumergimos en el vacío, y “Es preciso zafar de ese lugar vacío y descubrir un espacio donde las cosas tengan sentido, es decir, donde se pueda narrar" (PIGLIA, 2016, p.55).

Para ello es preciso salirse de sí, es necesario que la imagen de lo real tenga algo de extática para que pueda pensarse y asumirse que ésta puede generar relaciones, 
comunidad, conexiones emotivas en un conjunto heterogéneo de manifestaciones materiales de la memoria. Por este motivo no se perciben forzados el vínculo entre: los indígenas y los astrónomos ("Para los indígenas y para los astrónomos el agua es una idea, un concepto que es inseparable de la vida"); los telescopios y la búsqueda de los antepasados ("Para ellos, las estrellas eran los espíritus de sus antepasados. Entonces, ¿Qué buscan esos telescopios del norte? En el fondo buscan encontrarse con esos antepasados. Hacer del universo algo más cercano, verlo como algo familiar.”); el golpe de estado a Allende y la nostalgia de la luz ("Se oyeron voces que nunca antes habíamos escuchado. Allende empezó a devolver las tierras a los nativos. La libertad duro poco. Fue aniquilada por un golpe. En esa misma época la desintegración de una estrella supernova fue vista por un telescopio chileno. Era la primera vez que esto ocurría tan cerca de la tierra.”); el botón de nácar de Jemmy Button, el exterminio de los pueblos del agua y la desaparición forzadas de prisioneros políticos ("Al mirar cada uno de los rieles, aparecieron otros vestigios. Apareció un botón como último resto de alguien que estuvo ahí (...) Los dos botones cuentan la misma historia, una historia de exterminio. Es probable que haya muchos otros botones en el océano"). Entre la memoria por las almas de los muertos y la memoria del agua o del cosmos ("Los indígenas creían que las almas no morían y que podían vivir de nuevo como estrellas. (...) Se dice que el agua tiene memoria. Yo creo que también tiene voz. Si nos acercamos mucho podríamos oír las voces de los indígenas y de cada uno de los desaparecidos").

Figura 11: Selk'nam / Estrellas

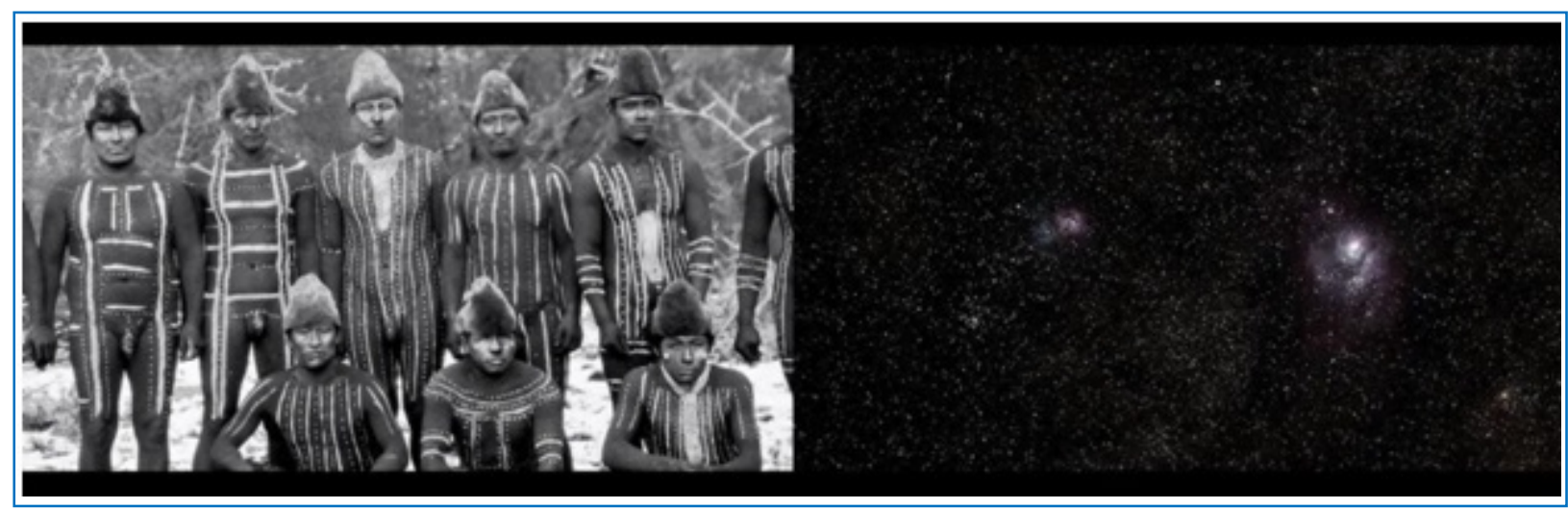

Fuente: El botón de nácar [Patricio Guzmán, 2012] 
Si en su momento planteamos que la imagen de lo real que Guzmán nos acerca es una disyunción, un corte, ahora también podríamos pensar que es un agujero negro. Es un punto en el universo de la historia de Chile. Un espacio cuyo interior contiene un océano, estrellas, pueblos del agua, desparecidos políticos, mujeres buscadoras, astrónomos, botones, palabras en kawésqar...todo está allí y cada 'materia' es un punto de evocación que irradia, resuena y se amplifica hacia todos lados, hacia cada uno de los testimonios, hacia los cuerpos que no están, hacia el mismo Guzmán, hacia nosotros... Aquello que irradia, quizá y con las concesiones que el caso nos permite, es memoria. Memoria(s), intrínsecamente polifónica(s), intrínsecamente conflictiva(s).

El agujero negro tiene gravedad. Esta provoca lo que físicamente se conoce como singularidad espaciotemporal. Y a su vez, esta está cubierta por una superficie que se llama horizonte de sucesos, que es una frontera imaginaria alejada de la zona central donde se concentra la masa del agujero. El horizonte de sucesos representa el punto de no retorno a partir del cual no puede existir otro suceso más que caer hacia el interior, es decir, no se puede salir del hoyo. Quizá, siguiendo el juego de palabras, podríamos pensar que Nostalgia de la luz y El botón de nácar proponen algo así como un punto de no retorno. Cada imagen que ingresa al relato no puede salir de este y tras ello, no puede existir, para quienes asistimos a tal caída, otro suceso más que creer. La creencia es, tal vez, una apuesta por un horizonte de sucesos, de sucesos que nos devuelvan la fe.

\section{Referencias}

BORDIGONI, Lorena. Entrevista a Patricio Guzmán, a propósito de su última película

Nostalgia de la Luz. Revista Cine Documental. n.5, 2010. Disponible en:

<http://revista.cinedocumental.com.ar/5/notas.html>. Acceso: 10 de abril de 2017

DELEUZE, Gilles. La imagen-tiempo: estudios sobre cine 2.Barcelona: Paidós, 1987.

DELEUZE, Gilles. ¿Qué es la filosofía? Barcelona: Anagrama, 1997. 
GUZMÁN, Patricio. El botón de nácar. Chile, 2015.

MIGNOLO, Walter. Historias locales/diseños globales: colonialidad, conocimientos subalternos y pensamiento fronterizo. Sevilla: Ediciones Akal, 2013, p.27.

PIGLIA, Ricardo. Las tres vanguardias: Saer, Puig y Walsh. Buenos Aires: Eterna Cadencia Editora, 2016, p.54-55.

SAER, JUAN JOSÉ. El entenado. Buenos Aires: Planeta, 2013, p.33

ZOURABICHVILI, François. El vocabulario de Deleuze. Buenos Aires: Atuel, 2007. 